\title{
JANUARY-1953
}

Mrs. John Hubbard, Grenfell, Sask.

It was a beautiful day, New Year's, when we went out to take our bird census, clear sky and hoar frost.

Birds were noticeable by their absence, but we found the usual flock of 100-odd Redpolls on the roadside weeds past the school. On to the Tiree road and turning north we notice the absence of bush rabbit tracks around sloughs and bush tho there hadn't been snow for a long time. In opener country we noticed one field where Jack Rabbits had made well-packed trails.

Down the Tiree hill into the Qu'Appelle Valley. Something new in colours there, a symphony of greys; the usual winter purples masked by hoar frost and mist away. in the distance. Just before ascending the hill on the north side I got out of the car. An almost summer medley of voices confused me. I called on John for aid. Before he got there a Ruffed Grouse let out a characteristic call and rustled away in the bush. A Blue Jay, also unseen, squawked and disappeared around a small hill. Some Redpolls drifted off ahead with friendly cheerful notes. Some other small birds with a call unfamiliar to me departed hurriedly and remained unidentified. In the distance Chickadees called.

John and I rejoined the noisy crew in the car and ascended the Tiree hill. On the road north to Neudorf John's eagle-like eyes picked out an Eagle coming our way. We stopped and eventually with glasses I was able to spot him-and adult Bald Eagle with white head and tail-the first adult Bald Eagle I've ever seen.

On north thru quite thickly bluffed country the odd Magpie but not as plentiful as last year, an odd Sharptailed Grouse and large flocks of Fedpolls. We counted some of Neudorf's Sparrows, and returned across the Qu'Appelle Valley by the Hyde hill. Springs were frozen in cascades on the north bank but in the Valley one was running and the river was partly open.

Home we counted our long-with-us flock of Pine Grosbeaks, our usually troublesome Hairy Woodpeckers, our own House Sparrows, and a Horned Owl that turned up late that after noon after I had remarked that they were getting scarce.

On the 5th of January we saw a Vesper Sparrow, very much alive and perky although it was around zero.

Bohemian Waxwings pay us the odd visit but they don't stay long. They evidently think the Pine Grosbeaks have priority on the dried crabapple crop in the orchard. The Grosbeaks have been here since November and varied in number from 12 to the present flock of around 25, and only one brightly coloured bird in the lot. The pup, always a bit crazy, also eats crabapples that he digs up, chews, and spits out the remains. The Grosbeaks eat large quantities of snow-John figures the fruit is pretty well dehydrated by now. They also feed on the honeysuckles and snowberries.

P.S. February 1, 1953: The Waxwings returned, 150 strong. They fluttered and rattled and denuded the trees of fruit. The ground beneath the trees was red with fallen fruit, which is now covered with snow. They left. I'm afraid the Grosbeaks have gone too-there's nothing left to eat.

\section{A Winter Canvas}

\author{
By Ray Peterson, \\ R.R.2, Tofield, Alberta.
}

When the gay, riotous, colorsplashed handiwork of autumn fades to the lonely, leaf-bare landscape of late fall, one is tempted to think that beauty has packed her luggage and departed for the winter. But Mother Nature, fortunately, is an artist at heart. She paints out the drab, dead remains of summer's luxuriant living with a bold, generous brush of snow. Then, in moments of sheer ecstasy 